\title{
An Analysis of the Similarities between The Peony Pavilion and A Midsummer Night's Dream
}

\author{
Chen Weiqin, Huang Chi* \\ School of Foreign Languages, Chengdu University of Information Technology, China
}

Received May 26, 2020; Revised June 24, 2020; Accepted July 29, 2020

Copyright $\bigcirc 2020$ by authors, all rights reserved. Authors agree that this article remains permanently open access under the terms of the Creative Commons Attribution License 4.0 International License

\begin{abstract}
The Peony Pavilion and A Midsummer Night's Dream are classic love plays created by Chinese Tang Xianzu and English William Shakespeare respectively. Their brilliant achievements in eastern and western dramatic literature have drawn widespread attention from many scholars so far. However, the comparison of the two works has not been studied enough. Although the two plays were created in China and Britain respectively, they shared a lot of similarities. This article aims to compare and analyze the two plays in terms of their setting of rebellious daughters and the tyrannical fathers and the employment of images, including dream and mythological imagery, and to demonstrate that under the influence of humanistic spirit and new cultural trends at the end of the 16th century. Tang Xianzu and Shakespeare, although living in different countries, were both committed to express the idea of opposing feudal ethics, fighting against asceticism, and advocating individual liberation. Their thoughts, together with $\mathrm{Du}$ Liniang and Hermia, the rebellious female characters in the plays, have influenced the literary creation of later generations. A comprehensive comparison and analysis of the two plays might help readers better understand the love thinking and ideological connotations of the two 16th-century writers in their different living environments.
\end{abstract}

Keywords A Midsummer Night's Dream, The Peony Pavilion, Comparative Study

\section{Introduction}

Tang Xianzu(1550-1616) was a Chinese playwright in the late Ming dynasty. He was born into a scholarly family in Linchuan, Jiangxi province, wherein four generations preceding him were all knowledgeable scholars. The Peony Pavilion is his masterpiece. William Shakespeare(1564-1616) was an English poet and playwright, widely regarded as the greatest writer in the English language and the world's preeminent dramatist. $A$ Midsummer Night's Dream is one of his greatest comedies.

The Peony Pavilion(1598), also named The Return of Soul at the Peony Pavilion, described the love story of Du Liniang, a young woman born in an official family, who was deeply influenced by feudal thoughts and bound by feudal ethics. In a colorful spring, Du enjoyed herself in the back garden after reading a Chinese classic Book of Poetry $\bullet$ Guan Ju, and then she fell asleep. She dreamed of an intellectual named Liu Mengmei who was breaking willow branches, and in the dream, they had a rendezvous by the peony pavilion in the garden. However, when she woke up, everything remained the same. From then on, Du became love-sick and depressed. Finally, she died in love-sickness. Three years later, Du Liniang's soul revisited the garden and rendezvoused with Liu Mengmei again. In the end, Liu dug up the grave and opened Du's coffin to help Du come back from the dead, and the two people got married.

A Midsummer Night's Dream(1594) narrated the story that Hermia, a young girl in Athens, was in love with Lysander, but Hermia's father, Egneus objected to their being together. Egneus asked Duke Theseus to sentence Hermia to death if she refused to marry Demetrius. Because Hermia loved Lysander, instead of Demetrius, she did not want to obey her father's order. Later, Hermia and Lysander decided to elope, while Demetrius, who loved Hermia, and Helena, who was infatuated with Demetrius, also followed the couple into the forest. In order to help Helena win the love of Demetrius, Oberon, the fairy king in the forest, ordered the elf Puck to fetch the juice of Love-in-Idleness and dropped it into Demetrius' eyelids while he was sleeping. The juice of this flower would make Demetrius dote upon the next live creature that he saw at first sight. Unexpectedly, Puck dripped the flower juice into Lysander's eyelids, which made Lysander fall madly in love with Helena. When Oberon heard about it, he 
quickly corrected the mistake and made Demetrius fall in love with Helena through his magic juice. In the end, Lysander was still loyal to Hermia, and Helena gained the love of Demetrius. All four were happy, and the two couples married at the same time as the Duke Theseus and Duchess Hippolyta.

A comparative study of these two works has aroused interest in the academic circle. There are comparative studies of The Peony Pavilion such as Shu-chu WEI, "Reading the Peony Pavilion with Todorov's Fantasies", in Chinese Literature: Essays, Articles, Reviews, Vol. 33 (2011). In addition, there are a number of articles in Chinese produced in 1993-2020 regarding the comparative studies of The Peony Pavilion and A Midsummer Night's Dream in different aspects.

\section{Role Setting}

Under the influence of humanism, the two plays with the same theme of love, A Midsummer Night's Dream and The Peony Pavilion, had some obvious similarities between them: there were voices of opposition, treacherous villains, and an external environment that was not suitable for love and so on. Despite the negative conditions one after another, the love between the protagonists did not wither. In shaping the characters, the two dramatists regarded the women with rebellious spirit as the main characters and portrayed their fathers as the main stumbling blocks on their road to happiness. In the patriarchal society, women were deprived of their chances to live independently, and they lost their subject status and became attached to men. However, the heroines of the two plays were not willing to surrender to this kind of imprisonment.

\subsection{Fathers as the Blocking Characters}

$\mathrm{Du}$ Liniang's father, Dubao, was the main negative character in The Peony Pavilion, who was not only the guardian of feudal ethics but also the representative of feudal bureaucrats and rotten scholars. Egneus, the father of Hermia, who must be an aristocrat as Dubao, was also a main negative character in A Midsummer Night's Dream. The two were quite similar in destroying their daughters' love.

From the main line of the love story, Dubao, a feudal parent and also a guardian of feudal ethics, always stood on the opposite side of Du Liniang and Liu Mengmei. At the beginning of the story, Du Bao set a variety of rules and precepts for Liniang, and he selected pedantic Chen Zuiliang as his daughter's tutor. To put it bluntly, He wanted to restrain Liniang from the mind and soul, kill her nature and desire, so that she can consciously follow the feudal dogma of "justice annihilate desire". Meanwhile, Du Bao chose the Book of Poetry, hoping that his daughter would become a moral model with the virtue of the concubine. In the last scene, to maintain his official dignity and face as a father, Du Bao did not recognize Liniang and repeatedly stressed that "my daughter died three years ago, but this woman looks exactly like her. It must be a flower sprite or a fox sprite assuming the human form", and begged the emperor "if you strike her with a cane, her demonic form soon appears" (Wang, 2000:953).

Coincidentally, regardless of Hermia's own wish, Egneus wanted her to marry Demetrius. After being opposed, he sued Duke Theseus and said "I beg the ancient privilege of Athens" (I., i., 44). What waited for Hermia was either execution or promising never to get married in the rest of her life. In Act IV, when the two couples were woken up from the dream and recognized their real lovers, Egneus still insisted to punish Lysander, "I beg the law, upon his head" (IV., i., 156).

Dubao and Egneus were the best representatives of the patriarchal power in the end of 16th century. Meanwhile, it can be seen that in the patriarchal past, no matter in which country, the low status of women was appalling.

\subsection{Female Representatives of Rebellious Spirit}

Du Liniang was born in a family that strictly adhered to asceticism. She couldn't step out of her room without her parents' permission. Her mother severely criticized her when knowing she traveled in the garden. Her teacher was an old pedant who deliberately interpreted romantic poetry as the carrier of "three obediences and four virtues" ${ }^{(1)}$. However, Du Liniang as a young and rebellious girl dared to pursue free love and denounce feudal ethics. In such a repressive environment, a fifteen-year-old girl longing for love died of depression, which was the greatest resistance she could make in such a social environment.

Du Liniang, with her praise of free love, pursuit of happiness and the yearning for an ideal life, embodied the rebellion and struggle against feudal ethics. Du Liniang's death did not mean the disillusionment of hope and the cessation of pursuit; on the contrary, it marked the beginning of her new life. In another word, she pursued ideals and happiness more boldly. After her death, Du Liniang completely got rid of the shackles of the feudal etiquette law, and she showed unprecedented boldness and persistence in love. In the face of Judge $\mathrm{Hu}$, she boldly admitted that she "died of lovesickness" (Xu, 2018: 104); when she happened to meet the person in the dream, she had no hesitation to "knock at his window screen" and let her soul "go nearer to him" (Xu, 2018: 125); in the face of her lover, Du Liniang frankly expressed her admiration for him. When her father forced her to leave Liu Mengmei, she said firmly, "If you want me to go back to the family of Du and leave the family of Liu, all my life I'll weep and hate you" (Wang, 2000:975).

The situation in A Midsummer Night's Dream is similar. 
Hermia was a maiden who dared to love and hate. She stood proudly without fear in the face of feudal despotism. She pursued personal liberation and freedom, resisted feudal oppression, and flouted feudal ethics and feudal laws. The freedom of women's marriage in the city of Athens where Hermia lived was also strictly restricted by a law, which was quite similar to the "three obediences and four virtues" in Chinese feudal society. At the beginning of the script, Hermia's father came to Duke Theseus to complain against his daughter, and if Hermia did not agree to marry Demetrius, he would beg the ancient privilege of Athens: "As she is mine I may dispose of her; which shall be either to this gentleman or to her death" (I.i. 43). However, Hermia still insisted on her choice. According to the Duke, if she yielded not to her father's desires, she would endure the livery of a nun and live all her life in a shady cloister. While Hermia said: "So will I grow, so live, so die, my lord, Ere I will yield my virgin patent up unto his lordship, whose unwished yoke my soul consents not to give sovereignty" (I.i. 81).

After that, Hermia became more rebellious and bolder, and she resolutely decided to elope with her lover Lysander. Her acts of disregarding the shackles of feudal ethics, ignoring the dignity of the court and fighting for her right to love, prominently showed the brave and fearless character of new bourgeois women.

Both Du Liniang and Hermia are females with strong life appeal and artistic appeal, representing what women suffered under the bondage of feudal ethics. The creation of such roles reflects the authors' praises of young men and women in pursuing free love, calling for personality liberation and opposing feudal ethics.

\section{Imageries}

An image is a visual representation that integrated into the author's thoughts and feelings, something endowed with some special meaning. In The Peony Pavilion and $A$ Midsummer Night's Dream, Tang and Shakespeare both chose to use the imagery of "dream" and mythological imagery to construct the story environment and told the stories in the absurd and fantastic background, which highlighted the difficulty of the protagonists' pursuit of freedom and love.

\subsection{Imagery of "Dream"}

Under the influence of romanticism, in the creation of The Peony Pavilion and A Midsummer Night's Dream, the two dramatists, who had no communication at all, used the art form of dream coincidentally, and the dreams in the two works had similar logical origins. In the dream, the protagonists experience self-liberation and self-awakening. At the same time, the authors integrated their understanding and hope of emotion into the image of "dream". To some extent, Du could only find the way to get rid of depression in her dreams, because reality couldn't give her hope, while in dreams, people are free to follow their own nature and heart. It was the same for Hermia when her dream became the sustenance of her yearning for beautiful love. Actually, the dream in these two works was a medium for the authors to show the core spirit to the readers, and this image was used as a scene for the characters to freely express their passion and bravely pursue love.

First of all, the Dream in these two works had a similar logical source: emotional depression in reality. For Liniang, the loneliness in the boudoir and the melancholy of youth prompted her impulse of love; in the meantime, the verses of Guan $\mathrm{Ju}$ and the brilliant scene of nature aroused Du Liniang's inner emotion and opened her long-imprisoned heart, thus giving rise to the longing for a happy life and the desire for love. Du Liniang and Hermia could not get emotional and sexual satisfaction in reality or express their love and passion, nor could they change the situation in real life by their own strength. Their desire for love and sex was suppressed by secular rules. Therefore, Tang and Shakespeare put their characters in an illusory state, which was not limited by time, place or the rules of real life, and solved their confusion in love in their dreams. In their dreams, they got close contact with nature and were able to freely express their passion and love, bravely pursue the freedom of love. If there were not so many rules and obstacles that hindered their pursuit of love, there was no need for them to experience sweet and painful dreams.

Second, a dream was not merely a process of self-liberation of the protagonists, but also a process of conflict between new ideas and old ethics. Both Du and Hermia both faced the conflict between freedom of marriage and secular rules. In The Peony Pavilion, Du was tired of the abstinence life arranged by her parents, however, if she hadn't dreamt of Liu Mengmei and fallen in love with him, perhaps her whole life would have been looking forward to the love described in The Book of Songs, and then following to her parents' arrangement of her marriage. The dream awakened her desire for love, so she spared no efforts to pursue the freedom of love. For Hermia, the experience in her dream was the catalyst for her self-independence. In addition, the dream helped her get rid of the conflict between the law and true love: if she didn't run away, she had no choice but to marry a man she didn't love. In the dream, these young people showed their enthusiasm and passion, and successfully broke the yokes of the secular world.

Third, the setting of dreams was the turning point of the story and the booster of development. Dreams were not only the result of their dissatisfaction with life but also the driving force of their awakening. The wonderful experience in the dream was an inspiration that promoted the awakening of their self-consciousness; at the same 
time, in the process of the dream, Du and Hermia gradually became brave. When they returned to reality, they, no longer considered as rebellious girls, were completely independent women with their own judgment. Hermia, with a stronger belief in her relationship with Lysander, had the courage to persuade her father again and became a woman with self-esteem and independent judgment. Du also experienced the process of "the living can die and the dead can live", breaking the chains of her own body and pursuing love in another form of life. These two dreams reflected the awakening process of people's self-consciousness and the spirit of self-development.

\subsection{Mythological Imagery}

In addition to successfully shaping a large number of lifelike young female images with shining humanistic ideals, A Midsummer Night's Dream also created a large number of supernatural images. Shakespeare organically interweaved reality and myth, mortal people and supernatural fairies with his superb artistic conception and originality. These supernatural people were supposed to be independent of the human world, but in Shakespeare's works, they all were shining with the brilliance of human nature.

In the forest on the midsummer night, there were fairy king and queen who quarreled like mortals, groups of immortals and elves, as well as bean flowers, spiders, moths and mustard seeds, who were indispensable roles in the forest. In particular, the benevolent and compassionate fairy king Oberon and the naughty and reckless elf Puck were the most prominent, since they played an extremely crucial role in the promotion of the plot, development and settlement of conflicts.

Oberon was moved by Helena's desperate and persistent love and asked Puck to lend a helping hand, and then he tried to clear the misunderstanding between the two pairs of lovers so that the lovers finally got married. The image of the fairy king was permeated with a strong humanistic color, which was also the embodiment of Shakespeare's humanism. Puck, the naughty elf, used the flower juice on the wrong man, causing the four young people to quarrel furiously. Under such circumstances, Puck said: "Then will two at once woo one. That must needs be sport alone; and those things do best please me that befall preposterously" (III., ii ., 123). When Oberon found out Puck's mistake and blamed him, Puck still joked: "So far am I glad it so did sort, as this their jangling I esteem a sport" (III., ii ., 376). These images' sentiment and desires reflected the characteristics of human nature, and the fairy world like the real one gradually changed from dispute to harmony.

There are similar mythological images in The Peony Pavilion, such as the Flower Goddess and Judge Hu. In Chinese traditional culture, flowers are often personified and gradually deified, thus winning the title of "Goddess of Flowers". In the literary works of Chinese Tang and Song dynasties, Flower Goddess was the embodiment of beauty. Until the Ming and Qing dynasties, with the prominence of the images of talented women in literary works, Flower Goddess was endowed with more independence. An obvious feature was that in the novels at that period, Flower Goddess came down to earth or many talented women became Flower Goddesses after death. Flower Goddess, as well as the sacrificial activities of the Flower Festival accompanying its appearance, not only enriched the daily life of the people but also left rich creative materials for literary creation. In The Peony Pavilion, the Flower Goddess, in protecting Du Liniang's love, acted as a symbol of independence and awakening of the female image. In fact, the emergence and development of the image of Flower Goddess in literary works also showed the evolution of female images from clinging to male chauvinism to independent awakening in Chinese traditional culture.

In The Peony Pavilion, Judge is a title of official position in the nether world, which derived from Hades Judge in Chinese ancient legends. Judge is responsible for judging ghosts who come to the underworld and has the power to sentence the reincarnation of life and death, to punish the bad, and to reward the good. In the play, the Flower Goddess pleaded with Judge Hu for Du Liniang, "Your Lordship, this maiden was guilty in a dream as whimsical as the morning breeze or the waning moon. Besides, her father is an upright official who has only one daughter. So will it please Your Lordship to remit her punishment" (Xu, 2018: 105). Then Judge Hu checked the Book of Marriage and agreed to release Du and let Flower Goddess protect Du's body, hence Du Liniang's soul finally met Liu Mengmei.

In addition to Flower Goddess and Judge $\mathrm{Hu}$, the use of mythological images, such as Chang'e, phoenix, flying fairy, willow elf, flood dragon, bluebird, toad and so on, had played an important role in shaping the ideological connotation, artistic style and characters of the works. These mythological images showed the employment of romantic style in Tang Xianzu's creation, which could not only fully reflect the ideological connotation of his "supreme emotion", but better shape the characters.

\section{Conclusions}

The Peony Pavilion and A Midsummer Night's Dream, represent some characteristics of Eastern and Western dramas respectively. However, there was a similar effect in the setting of roles and the use of imagery. Shakespeare and Tang Xianzu, the two great playwrights had the foresight to transcend their times, and they placed their good wishes for beauty and love in their works and their vivid characters. The contributions of Tang Xianzu and Shakespeare to their respective national cultures and even the world culture are inestimable. The influence of their stories on the world 
culture can be measured beyond language, and they might stand the test of time and will stand on the literary world stage forever.

\section{Notes}

In ancient China three obediences refer to the principle that a woman was required to obey her father before marriage, and her husband during marital life and her sons in widowhood; and four virtues include fidelity, discretion, physical charm, and propriety housework. Three obediences and four virtues acted as a tool for educating ancient Chinese women to be obedient, loyal to men in the feudal male-centered society.

\section{REFERENCES}

[1] Ayan Erdal. Analyzing Shakespeare's Emblem Language in Midsummer Night's Dream. Journal of Literature and Art Studies, 2017, (7): 1264-1278.

[2] Cui Weicheng. An Analysis of the Similarities between The Peony Pavilion and A Midsummer Night's Dream. Film Review, 2010, (5): 109-110.

[3] Ding Congrui. The Mythological Structure of Du Liniang's 'Rebirth' in The Peony Pavilion. Journal of Inner Mongolia Radio \& TV University, 2018, (3): 62-63.

[4] Fu Xue. Similarities and Differences between Shakespeare's and Tang Xianzu's Love Drama. Wide-angle Lens, 2017, (5): 271.
[5] Hu Zhiyi. Fantasy, Dream and Mythological Ceremony: Tang Xianzu's The Peony Pavilion and Shakespeare's A Midsummer Night's Dream. Arts Criticism, 2016, (10): 25-30.

[6] Huang Xinwen and Zhang Ai. Seeking Dreams, Pursuing Love_- On The Peony Pavilion and A Midsummer Night's Dream. Journal of Nanchang Hangkong University: Social Sciences, 2017, (19): 81-85.

[7] Kang Jie. A Comparative Study of A Midsummer Night's Dream and The Tempest. Overseas English, 2017, (4): 156-158.

[8] Li Niehai. Two Dreamlike Love Worlds-On the Relationship between dream and reality in A Midsummer Night's Dream and The Peony Pavilion. Comparative Literature in China, 2003, (4): 148-154.

[9] Sun Lu. The Image of 'Flower Goddess' in Chinese Classical Literature. New University Entrance Examination, 2014, (5): 35-36.

[10] Tang Xianzu. The Peony Pavilion. Beijing: China Intercontinental Press, 2018.

[11] Tang Xianzu. The Peony Pavilion. Trans. Wang, Rongpei. Hu'nan: Hu'nan People's Publishing House, 2000.

[12] Tang Xianzu. The Peony Pavilion. Trans. Xu, Yuanchong, and Xu Ming. Beijing: China Intercontinental Press, 2018.

[13] Wang Mengying. A Comparative Study of The Dreams in The Peony Pavilion and A Midsummer Night's Dream. Diss. HRBNU, 2016. 6 Oct. $2019<$ https://max.book11 8.com/html/ 2016/1126/65914280.shtm>.

[14] William Shakespeare. A Midsummer Night's Dream. Nanjing: Yi Lin Press, 2014

[15] Zhang Hanchi. On the Image of Du Liniang in The Peony Pavilion. Journal of Fuyang Teachers College, 2013, (4): 58-61. 